\title{
Critique of Public Administrative Reform System Post-Independence in Nigeria
}

ALADEGBOLA, Isaac Adegbenga | JAIYEOLA, Femi

\section{Abstract}

$\mathrm{T}$ e public service of any nation is its veritable instrument for national development. If it fails, the gamut of policies meant for the nation's development would have failed. In this sense, the observable developmental deficits in Africa cannot therefore, be separated from the failures of the continents public service and the largest chunk of these failures are located on the ethical behaviour of the public servants who are taking the service mostly as a colonial service. Writing from Nigeria hindsight, the author observed that most nation's public service in Africa, like its larger society, have not been able to separate themselves from their history, the history of "colonial mentality." In a way, an enduring problem noticeable within the public service in most sub-Saharan Africa (SSA) states has been what appropriate strategy will remove, the clove of "colonial mentality" associated with the public servant behaviour even years after decolonization of most SSA states and in spite of various post independent reforms put up to rectify these deficiencies. Has the knowledge of Africa Solution to Africa Problem (ASAP) instil the right type of ethical behaviours that will accept the public service as African service and not foreign service of the old exploitative order, divide and rule system and the 'not my business' syndrome that pervaded the era of colonial rules? It is critical that the failure of public service is a failure of service delivery in Africa. This paper, using Nigeria as a case study, does not only chronicle these failures/challenges as it affects Africa development strides, it also offers a process of public service ethics education as a strategy, in order to have long-term and sustainable solutions that will promote public service delivery in Africa.

Keywords: Public service, ethical education, service delivery, curriculum, colonial mentality. 


\section{Introduction and Background}

The public service has become a 'big business' in most part of Africa rather than a 'big service' for the people. In Nigeria for example, the dictum, 'it is business as usual' has become a soft verbiage for the high scale of rot and endemic corruption that has engulfed the various systems. Yet public service was designed to be an instrument for development. This paradox, though recently became a contemporary issue it is nonetheless a long history. This history is understandably long enduring because apart from playing a significant role in the process of policy formulation, the public service is also the vehicle through which governmental policies or programmes aimed at national development are translated into reality.

In a cursory observation, there is the temptation to assume that most of the issues that largely define the loci of what matters to citizens' everyday lives (the state of environmental health, education, water, crime and burgeoning demands for other social services) are the responsibilities of the government, but are all of concern to the local people. Often times, people are fobbed off by incessant excuses that passed from 'pillar to post,' often submitting that all these are 'not my responsibility' whenever people confront the leadership of the governmental units (Aina 2006:2).

The above situation is now further heightened by the fact that most developing nations of the world harbour a generation of too many people who cannot understand why their votes should produce so few results of democratic dividends, and whose main concern is, therefore, that the 'governors' should deliver basic services at reasonable standards, timely, appropriate and suited to the people needing them. Opposed to this, is a domineering distinctive characteristic of Nigeria's public service that the service has developed some habits that would take a long time to eradicate (Bolaji 2008:161). While this paper captures this as 'colonial mentality,' some expressed it as 'top-down working' and lack of delegation or trust in front-line staff whose attitudes are based on 'we know best' and 'it is not my responsibility' (Abdullah 2007:3). The result of which is shortage of high quality leadership. To some (Adamolekun 2004; Hassan, Ebele \& Raphael, (ed) 2007), it is about insufficient understanding about the people, the blind copy of foreign ideas; religion and federal character. Others (Ayedun 2007:108; Sehinde 2008:98; Uniamikogbo \& Aibieyi 2008:108) condemn public servants as too slow, too powerful, corrupt, lazy, and lethargic and colonially brainwashed individuals. These negative attributes run contrary to the role of government from time immemorial as it exists to 
add value to the quality of life of citizens through public policies, programmes and projects in virtually all facets of human endeavour.

It is a statement of fact that in pursuance of developmental goals and objectives, the most important tool available to government, be it big or small is the public service. Other sectors of the economy such as the private sector and civil society are also guided and controlled through the instrumentality of the public service (Abdullah 2007:4).

With respect to Africa, the developmental challenges facing the continent are, to say the least, endemic and daunting. The Gross Domestic Product (GDP) growth figures are increasing, but there are contentions on the reliability of data in most countries of Africa (Aladegbola 2012:280). While Nigeria's government claims to have the biggest economy in Africa, the poverty level has consistently remained high since 2004 (Aladegbola 2012:131). The best arguments by the statisticians are yet to succeed in dispelling the prevailing mistrust in the figures. In spite of the growth claims, only six African countries managed to make the list of the world's 100 richest countries in 2012 (Bolton - Akpan 2013:25). According to International Monetary Funds (IMF), sub-Saharan Africa is still home to a third of the world's poorest people. The 10 poorest countries in the world are still in Africa. Of the 10 countries with the world's highest levels of inequality, six are in Africa ((Bolton - Akpan 2013:25). Africa's phenomenon of 'jobless growth' had encapsulated poverty, unemployment and inequality increase despite impressive macroeconomic strides in several countries. In spite of the poor economic indices in Africa, the public service, over the years has remained an instrument of state action, in terms of effectiveness and efficiency of public service delivery.

The problematic issue in this study is that, to date, there is no evidence of a country that can coherently and prosperously flourish and develop without a capable public service. In the light of all these, a core objective of this study is to review the present state of public service delivery, albeit, in brief and in particular to identify the major lacuna to effective delivery of public services. The methodology employed is largely a content analysis of the secondary sources. The paper on this note, examines the panacea that should form a bedrock of reforms for the development of a more efficient and dynamic public service that acts as a catalyst for socio-economic development within the context of a democratic governance in Africa. In a historical and descriptive analysis, this study picks its local experiences from Nigeria as these are largely shared by most subSaharan African states (SSA), but again, it offers a suggestion that is African Solution to 
African Problems (ASAP) compliant and useful for all African countries with similar experiences and problems. The study advocates ethics education, starting from the formative years of the school children that will internalize values of efficiency, honesty and hard work since these are critical elements in service delivery which is on focus in the study.

\section{Conceptualizing public service as service delivery instrument}

In an attempt at weaving a conceptual background to this study, public service as service delivery instrument will appear in its more encompassing usage, which is public administration. The use of public administration as a broad concept will accommodate the two terms of civil service and public service as different, but of the same connotations and rules of operations. To avoid the rhetoric in the literature, the civil service in its modern sense is used to refer to the services of those that work mainly in government ministries and departments and which are paid from public funds approved by the appropriate authorities (Ademola 2004:39; Omotosho 2002:6). The public service is the same, but broader as it includes the services of those that work in other extraministerial departments or establishment like public educational institutions, public hospitals, corporations, commissions, statutory boards, local authorities and other publicly-owned agencies and who are also paid from the public funds. While the two are often used inter-changeably, the use of public administration accommodates the two. Both civil and public service is employed by the state through the Public Service Commission and they are empowered to see to the day-to-day running of government in terms of implementation of government policies using bureaucratic rules and regulations.

Public administration in the sense above was as a result of the rise of modern welfare states and an era of administrative state. It became inevitable, with the multiplication of state functions in the nineteenth century, where the old patriarchal, hereditary state officialdom was replaced by public bureaucracy (Basu 2005:1). Bureaucrats are recruited on the basis of public laws, performing largely within a legal framework, tasks which were becoming more and more public-oriented. Public administration is law in action; it is the executive arm of government (Olagunju 2001:94).

The changing face of public administration came with the industrial and commercial revolutions that actually brought government into industry and commerce. This business 
space was further widened by nationalism, imperialism and internationalism. The attendant results of increasing population, urbanization, public communications and mobility equally diversified governmental activities. Then, the evolution of democratic, totalitarian and socialist ideas actually transformed the concept of government. With the developments, people not only expect uniform national services today, but also expect public administration to reconcile competing class demands and conflicting interests in society (Basu 2005:1).

In the light of the above, public administration is indispensably present in all states, be they capitalist, socialist or developing in nature. In its modern sense, it has become public service, providing services ranging from post and telegraphs to transport facilities in cities and towns and has remained the main instrument of socio-economic transformation, especially in developing societies. In this sense, public service became the main instrument for service delivery as it touches on all aspects of citizens' lives from education to recreation as the society moved rapidly to over-dependence on the state. The recent vigorous and substantial private sector initiatives had presented some laudable argument against public administration, but Olagunju (2001:93) relying on extensive experience at public service, argues that the efficiency of the private sector depends on the existence of an efficient public service, not only in terms of the provision of infrastructural services and utilities, but also because of the ability of the government to respond to the complex needs of industry and commerce in the private sector. The role of public service is so crucial that if the conditions of reward and punishment in the public service become so unattractive that the experienced and skilled manpower in the public service migrates in large numbers to the private sector, the conclusion is that both sectors would collapse and the progress of the nation would be retarded.

In developing countries of the world, the public service as service delivery instrument has become a norm, and a high expectation as the high rise poverty level places the burden on all governmental arms to ensure the dividends of democracy to the people and the needed socio-economic development of the countries. Adedeji (1992:50) underscores these points when he opines that:

The ... civil service constitutes ... one of the ... groups in a developing country from which it is expected to flow a will and capacity to plan for the future of a society and to administer 
that society's human and natural resources so as to set the growth processes in motion.

In the same vein, Akande (2000:4) also states that:

The civil service is central to the performance of any government; it constitutes the tool for the formulation and implementation of an administration's policies and programmes. In ...democratic setting, and with clear mandate and policy objectives, government could not but rely on the civil service to translate into action all its political, social and economic policies.

Theoretically, Jennings' (cited in Basu, 2005:9) two major approaches to public administration support the thesis of public service as service delivery instrument. Jennings had offered 'bureaucratic approach' which takes efficiency and equal treatment of citizens as its primary values and the 'market approach' which on its own takes efficiency as its prime value, differing from the former in emphasizing diversity of products and maximum consumer choice (Basu, 2005:9). This study, like most writers (Basu 2005; Nnoli 2000; Olaleye 2004; Agagu 2001) of public administration, agree that some measures of market like matching of public services to consumer preferences, along with efficient and technically competent public management are desirable. This point of public service as service delivery instrument is further enhanced as it is generally agreed that in public interest, the government has to produce certain goods and services which would otherwise not be provided by private firms. These goods and services are called public goods. For example, they are public transport, education, water supply, employment or other measures of social welfare.

Beyond the point of government making decisions and implementing them, the above approaches assume the concepts of citizenship and democracy. In these concepts, a democratic government cannot be ultimately guided by a market model of competition and efficiency alone, but must bend normatively towards a citizenship model of government. In this way, a holistic view places business like management techniques in an instrumental position secondary to the bigger sphere of governance. It draws citizens, elected officials (policy makers) and the bureaucracy (policy implementers) together in the tasks of nation-building and socio-economic progress (Basu, 2005:9). This is the value of public service. This is variously tagged new public management, 
good governance and entrepreneurial government. On this, the 'new public administration' has emerged to shape the $21^{\text {st }}$ Century. Instructively to this study, its movement has incorporated 'ethical service,' one of the crucial elements in this paper. The new movement educates openness about the values being served through administrative action. It canvassed for a new public administrator who should be less 'generic' and more 'public,' less 'descriptive' and more 'client - impact oriented,' less 'neutral' and more 'normative' (Basu 2005:26). In this instance, the distributive functions and impact of governmental institutions should be public administration's basic concern. In addition, the purpose of public action should be the reduction of economic and social disparities and the enhancement of life opportunities for all social groups inside the organisation.

The crown of public service as service delivery gate is on the new public administration movement that has displayed an intense concern for societal problems (Stoker 2003; Mohit 2002). It stresses ethics and values, innovation and social equality. It lays great emphasis on human relations, a creative approach to administration and social change. The next section will examine the fundamental assumptions of these ethics in relation to this study and as applicable to most public services in sub-Saharan Africa.

\section{The assumptions of ethical service in public service}

The word 'ethical' is largely connected with beliefs and principles about what is right or wrong, it bothers on standard questions and what is considered normally acceptable (Longman Dictionary 462). This presupposes a moral quality of action, fitness and propriety. Taking a cue from the above definition, an ethical public service must reflect in its deeds, proper and fit conduct beyond reproach in the estimation of the general public. For example, the Nigerian civil service reforms have a mission as an effective change agent for reconstructing the public service to work for the people in the best tradition of globally cherished public service values (Shala 2006:19). It equally has a vision for public governance by a public service driven by public officers of:

Impeccable character and intensity, custodians of national interests and values, experts in the business of government and the management of resources and talents, for efficient service delivery and accelerated national development to meet the challenges of a globalized world (Shala 2006:19). 
Much of today's ethical service emanated from the philosophy of British civil service, based on the Westminster model. The British administrative philosophy does not associate politics with party loyalties, but rather perceive it within the context of the British constitution (Agagu 2001:83). It places emphasis on patriotism, confidence, trusted character, honour and self-reliance, emphasizing character formation and philosophical guide that makes government work successful, seeking efficiency and economy and perceiving administration as a product of civilization (Aladegbola 2005:25). In Britain, this has translated into 'merit system' and has led to the emergence of stable, reliable and non-partisan civil servants that would not mislead the Ministers irrespective of their political leaning. In other words, the principle of political neutrality is effective such that civil servants have to be apolitical. In spite of fusion of powers and the doctrine of collective responsibility, the British philosophy of administration is more inclined towards a balanced philosophy which paid equal commitment to ethical ideals.

Overtime, this foundation has been expanded in scope and in practice globally. Its expansion, and values and expectations in developing world and albeit in Africa entails its incorporation into public service codes of conducts, manuals, rules and regulations and reforms. Aina (2006:1) elaborates on these expectations, which is deliberately tagged 'assumptions of ethical public service' because of their high demands. Aina's submissions entail amongst others, conformity with and obedience of rules and regulations; a service composed of impartial public functionaries and selfless individuals; an even-handed crop of officials who facilitate equal opportunity to anyone who comes knocking at the doorsteps of government for one obligation or the other; a public service where corruptive tendencies have no place in matters of employment, recruitment or appointments; a service which is a reservoir of dedicated, committed and upright individuals to whom tasks assigned and set targets have to be accomplished satisfactorily and on time without manifesting any grudges, dislike, irritation or disdain towards the job at hand. The submissions here indicate that an ethical public service should not be a haven for glorified time-watchers and loafers but rather should stand for justice and fairness to all and sundry which are the hallmarks of such a service irrespective of language, creed, race, tribe, sex or social status of the person that are involved.

In an ethical public service, the watchword is service and productivity, which translates into doing an honest day's job for a commensurate pay provided by the 
employer. Service delivery pre-supposes that public organisations are expected to cater for public needs in all its ramifications, that is, utilities, social welfare, communication, etc. Indeed, anything the citizens expect to be provided by the public service. This becomes crucial nowadays because politicians and other stakeholders variously employ the concept, dividends of democracy, as a byword for service delivery. Arising from these noble expectations and theoretical assumptions, much consideration is given in this paper to the desirability of building an ethical public service to provide the right quality of leadership and quantum of service to the people. On this note, the next session focuses on situating public service in Africa in the context of public service as service delivery instrument and its interface with the required ethical behaviour.

\section{Situating Public Service in Africa}

On a global and general note, the public service has come to be regarded as modern institution bequeathed to mankind in the process of revolutionizing an efficient way of organising any large human organisation (Ipinlaye 2002:117). It is in this respect that the civil service is defined as a bureaucracy. However, over the years, the public service, like any other dynamic social institution, appears to have been caught up in the web of dialectical process. While this is a general phenomenon, the developing world and indeed sub-Saharan African countries seem to have been most affected. The reason for this is not far-fetched, because a significant feature of the political systems of developing countries is the increasingly central role that their governments and bureaucracy have come to play in the programme of development. In this regard, the very concept of government is undergoing a fundamental change in these countries. Not only has its role changed from governance by coercion, especially in Africa, to that of administration of public welfare but its activities are also assuming a new dimension. The new dimension now places more emphasis on implementing development activities. In addition, the global demand for democratic ethics is forcing states in Africa to move to welfare and social policies through changes in their economic and political systems.

It is quite clear that the capacity of developing countries to deal effectively with the problems of nation-building and modernization depend upon the development of coherent and viable political systems and effectiveness of bureaucratic role (Basu, 2005:117). To fulfil these tasks, the political system must evolve a participant 'civic culture' (which is ethical behaviour in this paper) to ensure sustained economic growth 
and promote national unity and consensus ((Basu, 2005:117). It should be noted, quite clearly, that the public service either in its present situation or in the immediate postindependence era has never been totally devoid of ethical values. In the first decade of post-independence African states, there was indeed a thoroughly ethical public service composed of a lot of selfless, honest and diligent officers to whom being a public servant was a great honour and rare privilege as such officers saw their appointment as a life-long career. To this class of officials, integrity, public image, carriage and social comportment carried immense premium and the work ethic was almost, to them, a religion. To the public at large, working in the public service was an invaluable opportunity and a special, but distinct advantages and officials were thus accorded tremendous respect and high social regard (Aina, 2006:8).

With time, in Africa, the administrative structure essential for formulating and carrying out operating programmes, suffer from many deficiencies in their framework. The experience in most African states went worse when the administrative agencies aligned with political leaders, leading to factional politics and rivalry between the departments. They also show a tendency towards acquiring independent power positions to increase their group interests. Worst still, their energies are more often spent in perpetuating their self-interest than in the pursuit of development goals. Generally, too, bureaucracy in developing countries is often perceived as short-sighted on enterprise, initiative and adaptability. They are also of slow act, arrogant and callous in dealing with the public. Currently too, administration in Africa is getting increasingly politicized. Political leaders and elected representatives of the people tend to control the administration excessively, interfere with its implementation process and bring unjust pressures and demands on it. While this is capable of checking administrative excesses and corruption, it is practically placing administration under politics thereby increasing the observable administration/ politics dichotomy.

The resultant effect of this dichotomy overtime has overshadowed the pride of public service as a lifelong career. To quite a large number of insiders and officers, it becomes a mere stepping-stone to a more lucrative and more rewarding pursuits. On the burdens of poor conditions of service, an attempt at making ends meet has more or less eroded the required dedication, commitment and selflessness. Contrary to what was obtained in Africa in early independence years of most countries, the public image of public servants 
and the hallmarks of an ethical public service have either gone into oblivion or declined considerably.

It is a sad commentary that an ethical and re-assuring environment has no place in today's public service. Politicians have impeded the elements of equity and fair play which the public took for granted in the past. Many officers on the job are well aware that nepotism, corruption and ineptitude are now part of the recruitment procedures in certain levels of employment, which are not under the management of relevant bodies or commissions. In Nigeria for example, before the advent of the "Due Process" philosophy introduced in the last five years, a lot of undercut dealings characterized public expenditure and the award of contracts. Abandoned projects, projects shoddily executed unfulfilled expectations, public frustration, disenchantment, general apathy and disdain towards the government in general, naturally became the order of the day.

In all of these woes, most African writers have traced the issues to an enduring, colonial public service history in Africa and the inability of most Africa nations to detach itself from a backward legacy and embrace public service as Africa service. This is what the next session places on perspective.

\section{Public Service in Africa: An enduring colonial mentality?}

It cannot be overemphasized that the civil servant, as an adviser in the formulation of public policies, and as the main instrument for executing such policies, is one of the key elements in the developmental process. The historical fact however, is that before the attainments of national independence of many African countries, public servants at the policy level were neither Africans nor servants, even if they were sometimes civil. During the colonial era, the expatriate District Commissioner or the administrator at headquarters was the 'big man' representative of the colonial bureaucracy and holds enormous power that ruled allotted districts. At the 1884/1885 Berlin conference, the emerging colonies of Britain, France and even Portugal in African territories produced political structures which were mainly administrative structure that were established piece meal. Even in French policy of assimilation, the colonial masters laid the framework for the evolution of a centralized bureaucratic structure. In most colonies, it was an imposition of a unified public or civil service. Generally, too, the imposed civil service was mainly concerned with the maintenance of law and order and the mobilization of enough African local resources in order to ensure that colonial administration was self- 
sufficient. The French territories that appeared to be different also went too far by regarding African culture to be inferior, and hence accommodated the policy of discrimination worse than the exploitation in the British territories.

The African experience is vividly captured in the Nigeria situation. The Nigerian civil service began as a force of occupation designed to facilitate colonial rule and the exploitation of the land and its people for the benefit of colonial authority (Adetoye 2002:88; Omotosho 2002:103). Moreover, like other African countries, the colonial civil service in Nigeria was not concerned with the growth and development of the Nigerian nation, but was more after the exploitation of Nigerians. Etuk (1992:4) captures this succinctly that:

The British-patterned, British-managed Nigeria public service was not established to improve the quality of life of Nigerians, or to raise the incomes and standards of living of the people, or to expand educational and job opportunities for the local population, or even to enrich their cultural life. Rather it evolved, grew, and remained an instrument for the protection of the trading interest of Britain and her sister colonial powers.

The above not only captures the nature and character of the Nigerian colonial civil service, it depicts the picture of oppression in African colonial public service. The system took Africans as second class citizens in their own country as nothing much was done during the period to settle the wide disparities, even the colonial reforms failed to place Africans in the administrative class of the civil service or the top-policy making positions of the colonial service. There were discriminatory personnel policies and practices between the colonial masters and Africans (blacks). The Africans that were fortunate to be recruited absorbed the wrong orientation that they were doing somebody else's job without any stake in the success and survival of the business.

After independence, most African civil servants became the servant of all and sundry, but the wrong orientation became strong belief system enduring till to date. In Nigeria, for example, many public officers believe that they are working for the government; therefore, there is no need to put in any extra effort (Omotoso 2002:104). This extraneous factor affected the set of dedicated, patriotic and neutral generation of civil servants that emerged after independence, having gone through the rigours of civil 
service career under the colonial tutelage. They were expected to accomplish the social and economic advancement of their new countries until the corruption of the new political class, the interruption of the military aberration in some African countries, the confusion that came after the several civil wars and endemic poverty affected the promising agency (Aladegbola 2005:26). Further frustrations led to the present selfseeking and nepotism, non-performing public service as it is often being described.

The argument in this study is that ethical problems started during the colonial public service. The departing expatriate senior servants contributed in a great way towards debasing the image of the top senior servant as the adviser and confidant in the decision-making process. The colonial masters pampered the emerging African political leaders who gradually came to see the disciplined civil servants as the major obstacle to their exercise of absolute power. In the Nigerian case and some other African countries who suffered early military incursions civil servants had an early exposure to power and money as they were relied upon by the armies for administration and management of government's businesses. The condition of service was a culmination of the long period of military rule during which authoritarian styles, mismanagement and corruption were progressively allowed to permeate the system and reign at the expense of good governance and service delivery. It was natural that public service as an integral part of government could not have maintained itself as an island of efficiency and integrity in that era. The resulted politicization and corruption had so deeply affected whatever ethical orientation that was inherited from the colonial bureaucratic policies.

Once more, many of the top African civil servants themselves were not properly equipped or had the mind set for their new role of advising the politician on the running of modern government, particularly in the context of national economic development (Aladegbola 2005:24). Many of them were brought up through the tradition of the colonial civil service and were trained mainly on routine administration. Many of them did not also have the experience required for the task of nation-building in many areas of governmental economic activities as demanded by their young countries. This factor did not only affect the substance of needed ethical qualifications possessed to be qualified for the various positions, it created an early administrative gaps at various levels for purposes of planned administration, more so that many of the civil servants were not in the position to present their advice even when they have good ideas. 
The $21^{\text {st }}$ century phase of this problem is being compounded by the orbit of globalization taken its toll on all nations, including African countries. The complexities arose from the role of norm, institution and behaviour of governments as the world shows different value systems among different cultures. Worse still, different types of personalities operate the varieties of institutions and sometimes manipulate them. Added to this in Africa are the wide range and character of the background of nations, the numerous nation-states with different ideologies and at different levels of development, political culture, norms, institutions and behaviour in government no doubt complicate the task of achieving a stable, virile and functional ethical behaviour in Africa's public service system.

The situation became worrisome in Africa as it is very clear that nations do not become great by the virtue of their wealth, but by the wealth of their virtues and ethics. For example, Switzerland has few natural resources compared to most countries in Africa. However, it is a much healthier, wealthier, and most just and stable country than any country in Africa. Switzerland's wealth is in its moral fabric and the value system of its people (Adelaja 2008:42). The country has made much more of its comparatively meagre resources than any African country had made with its great natural wealth (Adelaja 2008:43).

Unfortunately, the good culture in Switzerland is missing in most public services in sub-Saharan Africa. This aspect of the paper has shed light on the genesis of the enduring problem. It has shown that a close study of Africa's colonial history vis-à-vis the development of Nigeria's public administration reveals that there are still the indices of colonial mentality in the public service (Aina 2006). The British public service structure and procedure for example perpetrate the mentality of 'no one's businesses in government enterprises (Aladegbola 2005:36). The work of government is never done or finished, but continues until eternity. To them, it is folly for anyone to speed up or apply degree of industry to a job that is never supposed to be completed, but last for generation.

It is an obvious fact of history that the above scenario and odd orientations had affected the all-important service delivery as expected from the independent African states. While the subsequent governments in Africa have not been idle, as far as proffering solutions that will correct the system, especially in terms of multiple reforms, the big question however is whether the various reforms have actually addressed the 
source of the problem discussed in this aspect of the paper. It is this critical issue that the next session addresses.

\section{Reforms and Service Delivery Expectation of the Public Service in Nigeria}

No single paper or study can exhaust the sordid list of crass administrative ineptitude and disquieting unethical practices in the public service, which culminated in poor service delivery to the public. Suffice to say, however, that there have been several government public service reforms to reverse the unedifying trend. The implications here are that the public service reforms have been the key issue in finding answers to dimensional ethical problem of public service in Africa. (Hassan, Ebele and Raphael 2007). In putting this into perspective and an attempt at the chronicles of the history behind it, Nigeria is picked here as a suitable case study. Apart from its familiarity to the authors, Nigeria had been a huge history of public service reforms within the comity of other African countries. This is apparent possibly because its public service system has suffered an unexpected strong setback or decline that had impeded national development in spite of the nations' massive natural endowments. From preindependence, the colonial masters had offered piecemeal reforms, aimed at pacifying the continuous nationalist demands for more participation of the people in the affairs of the country rather than the aim of providing for socio-political and economic advancement of the colony. The post-independence reforms came to correct the many damages occasioned by the military usurpers and the clueless corrupt civilian administration reluctantly enthroned by the military elites at their departure. The reforms, at both divides, ideally have one major focus. It was expected to achieve service delivery. The question however is, did it?

Service delivery had been an old concept which draws attention of organisations to their responsibility to render service to their customers, in the most satisfactory manner (Shala, 2006:22). It largely presupposes that in public service, there is a contractual relationship between the customer (the public) and the service provider (government agency), which obliges the latter to render service to the former in the most satisfactory way, in terms of utility, quality, convenience, timeliness, cost, courtesy, communication, and otherwise (Shala, 2006:22). Another presupposition is that just as in business, the 
customer is regarded as 'king', therefore in public service delivery, and the public is regarded as 'master' and should be the ultimate judge of performance.

It is necessary to observe that most public service reforms in Nigeria as in any other African country have the service delivery expectations of the public service. They connote the following items:

- An organisation that is staffed with competent men and women and is well managed;

- Courteous, friendly, receptive and helpful relationship with the public;

- Eager and pro-active offer of information to the public with feedbacks and follow-up;

- Transparent, honesty and averse to corruption, fraud and extortion of the public in official dealing;

- Exemplary standards of efficiency in production and rendition of services, with minimal waste;

- Punctuality and time consciousness in all official business;

- Well-planned programmes with activity schedules and calendars that are firm and respected;

- Prompt response to problems and complaints of the public, which are conclusively attended to;

- Objective, professional, fair and patriotic treatment of matters of public interest or cases entailing competition among persons or organisations;

- Services and products that are almost of cutting - edge standard and rendered with minimal need for members of the public to leave their homes to visit the office concerned or to spend substantial amounts of money or provide copious documents and passport photographs;

- Charges and billing systems that is affordable and convenient to the public;

- Public infrastructure facilities that are built to unblemished standards, regularly maintained and promptly repaired, and 
- Continuous improvement in service mix and methods based on communication and feedback from the public (Shala, 2006:22).

An objective assessment of Nigeria's public institutions shows that they are mostly far from meeting these lofty expectations, which are largely taken for granted in other parts of the world (Aladegbola 2006, 2012; Akindele, Ajisafe \& Olaopa 2002). As the colonial masters were careful in tampering with their entrenched divide and rule system, the piece meal reforms meant mainly to satisfy the agitations of the nationalist leaders, demanding for the participation of more blacks in governance of Africa ended up giving African civil service a class structure that was alien to African traditional systems and culture. The re-organisation created jurisdictional and other related problems in the civil service since there were conflicts among the general service classes on the one hand, and between the administrative class and the professional class on the other (Ovwasa 2004:60).

The post-independence reforms in Nigeria were targeted at finding ways of infusing efficiency and effectiveness into the public service. It was a huge challenge for a new state yearning for development, especially as the expatriates were withdrawing in both political and the administrative life of the nation; having laid a poor foundation of class system for Nigeria as a nation and now left with new emerging leaders, though honest, but lack the experience and were soon to see the reality of governance as the gap between promise and performance steered them in the face (Aladegbola 2013:1). The big problem with the civil service at that time was that the political change at independence was not accompanied with appropriate administrative change. The complexity of emerging new nation's development problems soon exposed some of the inadequacies of inherited Westminster-style of administration. As emphasis shifted to implementation of various development programmes, the colonial procedures of the service increasingly failed to cope (Agagu 2003:250). The gains made at the colonial and post-colonial public service reforms and the 1970's oil boom in Nigeria were wasted and destroyed during the long military rule and the attendant civil war. Though the military attempted some reforms, re-organisations and mass purge of the service, they created serial problems of corruption and autocratic bureaucracy of imperialism, sordid materialism and incompetency. The class conflict relating to crisis of capitalism that 
started at the colonial service developed into unimaginable problems during the military rule in Nigeria.

In 1999, the new civilian President (Chief Olusegun Obasanjo) and his government knew they had so much to attend to with the level of depravity at all levels of public life in Nigeria. The President came out with staggering reforms that were quite daring, comprehensive and all-encompassing. It had been christened Obasanjo reforms (Shala 2006:1). It was of a long range of reforms which are listed here:

- The 1999 military restructuring,

- Reforms on national integration, electoral reforms and Niger Delta,

- The due process,

- The national political conference,

- The Economic and Financial Crime Commission (EFCC),

- The Independent Corrupt Practices and other related offences Commission (ICPC),

- The banking sector reforms,

- The bureau of public enterprises as agency for privatization,

- The deregulation of the oil sector,

- The monetization of workers benefits,

- The National Economic Empowerment Development Strategy (NEEDS),

- The Nigeria Police reforms,

- The poverty eradication reforms,

- The pension reforms,

- The liberalization of the communication industry,

- The national identity card projects and the classic introduction of high powered professionals into governance and civilian administration among others (Aladegbola 2005:66-68).

Specifically, the government organised a retreat on service delivery in Nigeria on the $21^{\text {st }}$ of March in 2004, where the Federal Executive Council entered into a Service Compact with all Nigerians (SERVICOM). The provision entails quality services designed around the requirements of the customers and served by staff sensitive to the needs of the clients. This was done after the 2003 formulation of the National Economic Empowerment and Development Strategy (NEEDS) as a framework for integrating into an 
organic entity, all sectoral reform initiatives that hitherto existed as independent actions, in order for them to be properly aligned within the overall goal of promoting good governance and accelerated national development. The government further raised a national council reform, tagged the 'Bureau of Public Service Reforms' and chaired by the President himself. The focus of Nigeria's public service reforms on budget and financial management accountability issues, human resources management and operation and systems are all targeted at improving service delivery and promoting good governance (Umeano 2012:43). Currently, Nigeria is pursuing an enlarged and ambitious vision 2020 where it hopes to be one of the 20 largest economies in the world by the year 2020 .

In spite of the efforts of the reforms, there has been little or no departure from the old order. Expert observers at various fora are still painting the picture of lethargic and slowness in official decision and action, insensitiveness to the value of time, irregularity in the attendance at work, nepotism, wastefulness of government resources, high corruption scales, slowness to change, unresponsive and discourteous attitude to the public among several others. Experiences of contractors and other members of the public who visit government ministries for transactions or even to merely seek information still indicate the poor ethical behaviour.

Arising from this position, this study is of the strong opinion that the various reforms as good are the intentions are, were more of Eurocentric ideas rather than African. They failed to recognize and accommodate the African ecological aspirations and belief systems. Arguably, it is an imposed culture. These reforms went far to arrange and rearrange the environment, but has no capability to change the mind-set of the practitioners and the stakeholders. The simple logic here is that Africans do not have the education of the system they are required to practice.

\section{A critique of the reforms}

The public administrative system in Africa is alien and imitative rather than indigenous. It has failed to put into consideration the Africans socio-economic variables as different from the imposed ones. Despite the catalogue of reforms, Nigeria, for example, has failed to effect strong central direction and effective bureaucratic performance of the service due to the mentioned foundational problems. At independence, the emergence of the elites or the comprador bourgeoisie nationalist started on a false ideology. They 
had the political power and one would have expected a concrete and visible direction, where an efficient and progressive civil service would have been nurtured, but the leaders were selfish. They placed primordial and ethnic interest above national interest. For example, the Nigerianisation of the civil service that came with the independence became an administrative blunder as it does not produce well-trained and experienced workers. The vacancy created by the departure of the expatriates was filled without strict adherence to merit, professionalism and experience.

\section{Providing public service ethical education in Africa}

The argument in this paper so far has portrayed public service ethical problems as arisen from long-standing foreign indoctrination of African minds of an ideal moral virtues of honesty, hard work, communal living, name integrity, satisfaction, religiosity, hope, sharing, neighbourliness and 'my brother's keeper' and has entrenched the Western world's capitalist exploitation in the public service as retained from the colonial mentality. The quest for African Solutions for African Problems (ASAP) and the dire need to change the orientation or to re-orientate the future of public servants requires all attention to input and incorporate Africans' positive belief system into their national curriculum. This is more imperative as the failure of African people to recognize and react to strategic threats from the point of view of their own interests in itself the most catastrophic failure of African people in the last two millennia (Kimani 2013:2).

Against this background, this study is calling for an adoption of ethics education which targets youth at their formative years. It holds that the much reforms and the inservice training to effect public service efficiency in relation to service delivery remains a belated enterprise that does not internalize values and therefore cannot achieve much result. The emphasis on ethics education should therefore start at the lower levels which prepare the individuals to have a better understanding of the societal expectation of individuals, it also becomes a potential for the foundation that prepares individuals to reach their best and be self-actualized, contributors to life, have purpose in life, selfrespect and consequent respect and appreciation of others. In a way, it prepares the individuals to appreciate and collaborate with their fellow humans.

At the centre of human survivability lies the role of ethical education, not as guarantor of absolute development, but to ensure human values continue without fear of extinction. The present global reality of service delivery expected of the public service 
anywhere compels every nation to employ different approaches to manage the recurring failures of public service. Africa, having stayed behind for long in matters of development, need to start the process of inculcating ethical values to the future generation of African leaders. African countries need to develop a curriculum that will accommodate its ecological factors, and teach values that are peculiar to their natural tradition. Such education may build up a long-term culture of honesty and dignity that will normally translate to service and productivity expected in public service. This curriculum should be so designed that the content for learning will provide for civil orientation, conformity with and obedience of rules and regulations as against the present lawlessness in Africa. It must be a curriculum aimed at raising a future service composed of impartial functionaries and selfless individuals, an even-handed set of officials who facilitate equal opportunity for all, an incorruptible mind, a reservoir of dedicated, committed and upright personalities who will be proud of the 'old black' integrity, originality of culture and family life.

In attaining the above, the real meaning of curriculum should be upheld in relation to Africa's natural values as against the adoption of foreign imposition of orientations. In this sense, a curriculum is a range of learning experiences which aim to provide the learner with the values, knowledge, skills and techniques that are appropriate to their needs and those of their group and society. On this note, building a foundational ethical public service for improved service delivery in Africa requires the need to build a curriculum that has the underlying cultural values of Africa in content, teaching materials and contains the inspiration and theories that supports the belief system. Any curriculum that lies outside of the cultural and historical tradition of its learners is certainly going to create a distinction between such a curriculum, the learner and the values it is meant to inculcate. An appropriate curriculum is one which responds to the educational needs of the people it serves. Kimani (2013:2) points out that there are local and regional variations but that the identity and educational needs of the African people are broadly similar because the characteristics of the African people are the same or similar.

Having stated the need for Africa ethical education, it must however be conceived at the primary level and continued at secondary and post-secondary level of education. The compelling role of government is to consciously make it compulsory and thereby institutionalize the programme. The logic of primary level is that the formative stages of the youth is extremely important as this may shape a strong determination on whatever 
the youth may believe or do in the future. If the ethical values are indoctrinated and inculcated as part of his or her values, the tendency to understand the expectation of his or her society will be made clear. Although this may not always be the case, but there is a strong relationship between what children learn when they are young and what they take to in their future development.

The education here which normally begins with an informal method through the family institution as primary agency of learning is common in Africa. Before the advent of formal education, an average African child received from his or her parents such knowledge that equipped them for the development of themselves and that of the society in general. The evolution of public service ethical education will find appropriate impetus of the informal training from home that will serve as the ultimate tool for changing the present crave for selfish interest in public service. The general development of public service ethical education could further be extended to the subject of religious studies. The religious appeal in Africa is high and the subject of religion has a moral and ethical compelling factor on children and that of history and civic education. The two subjects need re-introduction as it will arouse the passion of patriotism, nationalism, Pan-Africanism, love and devotion to the black race. This will have an overall positive effect on exhibiting the essential culture of service delivery. The lessons on African history should focus more on the positive aspect of living, togetherness and brotherhood.

\section{Conclusion}

This study is carried out to find a strategy that will address the long enduring 'colonial mentality' in terms of poor attitudinal behaviour towards public service in Africa. It has been an attempt to redefine Africa public service from the old colonial mentality to a more meaningful African culture of post-colonial relocation. Using Nigeria's experience, the study has chronicled the failures of several reforms in a bid to reposition Africa's negative ethical behaviour inherited from the colonialist capitalist-modelled public service. The present dire need for service delivery required from our public service and the current notion to bring African solutions to tackle African problems, if well situated and pursued, may bring the desired African development. It is expected that learning about public service ethical education in Africa as suggested in this study will go a long 
way to address the long failure of public service in Africa as service delivery instrument for socio-political and economic development.

\section{List of References}

- Abdullah, S. 2007. 'Enhancing Leadership, Public Service and Democratic Governance for Development in Nigeria'; Being a text of a Lecture at the Ekiti State Quarterly Public Service Lecture; November, $22^{\text {nd }}$

- Adamolekun, L. 2004. 'Re-orientating Public Management in Africa: Selected Issues and Some Country Experiences. ERWP No 81, Tunis Belvedre, African Development Bank.

- Adedeji, A. 1992. 'The Political Class, The Higher Civil Servants and the challenge of Nation-Building in Effective Leadership. Proceedings of the Ministerial Workshops on the Nigeria civil service Reforms of 1988. Ibadan: Spectrum Books Limited.

- Ademola, P, 2004. 'The Public Service and National Development' Ado-Ekiti, University of Ado-Ekiti. PhD Seminar paper, Department of Political Science, University of Ado Ekiti, February.

- Agagu, A. 2001. Comparative Political and Administrative studies. Ado-Ekiti, Department of Political Science; Ekiti State University.

- Agagu, A. 2003. 'The changing phases of the Nigeria civil service' in D Kolawole (Ed.) Readings in Political Science. Ibadan: Johnmof Printers

- Aina, O. 2006. 'Building an Ethical Public Service for Improved Service Delivery in Africa' $A$ Public Service Lecture. Ado-Ekiti, June, $19^{\text {th }}$

- Akande, A. 2000. A fresh start in Osun State. Oshogbo, Osun State Government Press.

- $\quad$ Akindele, S., Ajisafe R.\& Olaopa, O. 2002. 'Public Enterprises Management in Nigeria. In F Omotoso (Ed.) Contemporary Issues in Public Administration. Lagos: Bolabay Publishers.

- Aladegbola, A. 2005. Issues in Nigerian Public Administration Ikere-Ekiti. Department of Political Science. College of Education.

- Aladegbola, A. 2006. 'Privatisation and Commercialization policies in Nigeria. In A lyela and F. Audu (Eds) Social Studies for Higher Education Students. Kaduna: Sunjo Publishing Co. 
- Aladegbola, A. 2012. 'An Appraisal of the National Poverty Eradication Programme, 20012007' PhD thesis, Department of Political Science, University of Ilorin, Nigeria.

- Aladegbola, A. 2013. 'Fifty Years of Poverty and Inequality in Africa: Between Failed Responses and New Options. Paper presented at Africa Institute of South Africa (AISA). May 20-21, 2013

- Ayedun, F. 2007. 'Public Service Administration in Osun State'. A Lecture Delivered to the Students of Political Science, College of Education, Ikere-Ekiti, Ekiti State, July, $4^{\text {th }}$

- Basu, R. 2005. Public Administration: Concepts and theories. India: sterling publishers Private Limited.

- Bolaji, K. 2008. 'Rethinking Public Service Reforms in Nigeria' in Salihu, Taiwo, Seniyi, Salewa and Usman (eds) Nigeria Beyond 2007. Issues, Perspectives and Challenges. Ilorin. University of Ilorin. P 161-177

- Bolton-Akpan T. 2013. 'Africa rising: Between myth and Reality' Lagos; The Punch, Nigeria Daily Newspaper. Friday, November. 8. P. 25

- Etuk, E. 1992. The Nigerian Public Service: In search of Creative Excellence. Nigeria: Spectrum Books Limited

- Hassan S, Ebele A \& Raphael O (Eds) 2007. Nigeria's Reforms Programme. Issues and Challenges. Ilorin, University of Ilorin, Faculty of Business and Social Sciences

- Ipinlaye, O. 2002. 'The Nigerian Civil Service: An Insider's View' In F. Omotoso (Ed.) Contemporary Issues in Public Administration. Lagos, Nigeria: Bolabay Publications (Publishing and Media Consultants). PP 117-131

- Kimani, N. 2013. 'A Pan African Curriculum and the Development of teacher Quality and Quantity: Necessary Aspect of African Unity and Development. A paper presented at the $3^{\text {rd }}$ Annual conference on scramble for Africa. Pretoria, South Africa. 20- 21 May, 2013

- Longman, 1995, Dictionary of Contemporary English, New Edition. England: Pearson Education Limited.

- Mohit, B. 2002. Social Theory and Development Administration. New Delhi, Jawahar Publishers pp 129-142

- Nnoli, O. 2000. 'Public Administration;' in Mukandala Rwekaza (ed) African Public Administration: A reader. Zimbabwe AAPS Books 
- Olaleye, A.O. 2004. Fundamentals of Public Administration. Ado-Ekiti. Yemi Prints and Publishing Services

- Olagunju, J. L. 2002. 'The Roles of Civil Servants in Nation Building' in Omotosho (ed) Contemporary Issues in Public Administration. Lagos, Nigeria: Bolabay Publications. pp 93101.

- Omotoso, F. 2002. 'The Nigerian Civil Service: An outsider's views' in F. Omotoso (ed.) Contemporary Issues in Public Administration Lagos, Nigeria: Bolabay Publications. pp 102-105

- Ovwasa, L. 2004. 'Administrative Reforms in the Nigerian civil service since independence: A Retrospective Analysis. Political Science Review Vo. $3(1,2)$ March: 60 - 67

- Sehinde, B. 2008. 'Need for a Review of Statutory Roles of Local Government for Effective Service'. Journal of Contemporary Politics Vol. 1 (1) 98 - 107

- Shala, D. 2006. Not Business as usual: The Obasanjo Reforms. Abuja, Nigeria. D. S. Research and Publishing Co. Ltd. p 19

- Stoker, G. 2003. 'Governance as Theory: Five Propositions' in Bidyut Chakravarty and Mohit Bhattacharya (eds), Public Administration-A Reader, New Delhi, OUP.

- Umeano, T. 2012 INFO, Abuja, Nigeria, Verity Niger Dimension

- Uniamikogbo, S \& Aibieyi, S. 2008. 'A critical Analysis of the Monetization policy in Nigeria.' Journal of Contemporary Politics. PP. $108-130$

\section{AUTHORS' CONTACT:}

\section{ALADEGBOLA, Isaac Adegbenga}

Dept. of Political Sc. \& Public Admin. Adekunle Ajasin University Akungba, Nigeria Email: stainlessade2004@yahoo.com

\section{JAIYEOLA, Femi}

College of Education Dept. of Teaching \& Learning

Washington State University

Pullman, Washington

Email: femmer99@yahoo.com 